\title{
Ethno-Veterinary Medicine (EVM) and Traditional Practices in Animal Health Care System (AHCS) in the Southern Part of Rajasthan- India
}

\author{
${ }^{1}$ G.S. Deora , ${ }^{2}$ M.S Rathore \\ ${ }^{1}$ Taxonomy and plant diversity Laboratory, Center of Advanced study, Department of Botany, Faculty of \\ Science, Jai NarainVyas University, Jodhpur (Rajasthan) 342005, India. \\ ${ }^{2}$ Department of Botany, Faculty of Science, Bhupal Noble's University Udaipur, (Rajasthan)- 313001
}

\begin{abstract}
:
In tribal dominated areas of Rajasthan, the use of plants in primary health care system is an integral source of easily available remedy for their domestic animals. The tribal people still depend on traditional herbal medicine suggested by traditional medicine man or traditionally knowledgeable health practitioners or ethno-veterinarian. This study was conducted in the tribal dominated belt comprising with six districts namely Banswara, Dungarpur, Chittorgarh, Pratapgarh, Rajsamand and Udaipur. The area is dominated mainly by Bhil, Meena, Garasia and Kathodia tribes. The ethno-veterinary medicinal information was collected by interviews, group discussions and give and take methods with the tribal knowledge men or ethnoveterian and traditional animal health practitioners. In the present investigation herbal formulations of 19 plant species belonging to 14 families have been documented from the different areas of the study sites.
\end{abstract}

KEY WORDS: Ethno-veterinary medicine,Traditional practitioners, Tribal people, Ethno-veterinian .Animal health care system.

\section{INTRODUCTION:}

The ancient civilization of India, China, Greece, Arabic, and developed countries developed their system of medicine in independent of each other and all of them were pre dominantly plant based. Infect an unconscious selection of plants for use as drugs probably began even before the dawn of settled civilizations.

Almost all villages in India we can find that people of any cast or community who treat different diseases of their livelihood with the local herbal plants or "Jaributtis". These practitioners are known by different names at different places such as Vaidia (Bihar) Ojha (Jharkhand) Vaidhyaraj (Gujarat) Gunies (Rajasthan) Dangabhagat in Maharashtra. But by different literature of the world they are called as tribal doctors, bare footed doctors, herbal doctors tribal medicine men, folk healers, folk and laymen practitioners etc . The international origination such as WHO, IUCN and WWF have recognized them as traditional health practitioners (THPs) (WHO 1993) .

In India the world health assembly took note of vital role of that traditional medicine play in health service, particularly the remote areas and draw attention to manpower reserved constituted by the traditional practitioners (resolution WHA 29.72). About 80 per cent of the total world's population resides in the developing countries and about 64 percent of total population of the world civilization utilizes plant based drugs.

People's traditional knowledge practicing to animal health care system (AHCs) and production is known as ethnoveterinary Medicine (EVM). McCrokle (1972). This term recognizes the cultural context of traditional practices; EVM is as old as the domestication of various livestock, animal species. At a time when modern techniques were not 


\section{G.S. Deora ${ }^{1}$,International Journal of Ayurvedic\& Herbal Medicine 7(4) July.-Aug. 2017 (2746-2751)}

known, it was natural for the primitive man to try various herbs. Plants and their products present in his surrounding as medicine for various ailments Inflicting him and his medicine thus many ethno-veterinary practices and medicine were identified and authenticated in time to come based as the experience therefore they completely rely on plant based medicine for themselves as well for their animals.

\section{MATERIAL AND METHODS:}

\section{Study area and dominated tribal community}

The study area of present investigation was southern part of Rajasthan. The major tribal dominated are of the state includes Banswara, Chittorgarh, Dungarpur, Pratapgarh, Rajsamand and Udaipur. These areas are dominated by Bhil, Meena, Garasia, Gameti, Damor and few communities of Kathodia. The main occupation of these tribals is agriculture, livestock, and to collect forest products. These tribals' communities are far away from the modern facilities of medicine for themselves and their domestic animals.

\section{Data Collection:}

Ethno-veterinary- medico - botanical surveys were conducted in tribal dominated areas of the study sites to collect information about the medicinal plants uses for animal health care systems and various practices adopted by the local traditional practitioner nurse to give the herbal doze to their domestic animals.

The present study was based on extensive surveys and an interview. During surveys group discussions and personal interviews were conducted with the ethnic groups of the study area. During discussions local name of plants, their uses to cure various animal diseases were recorded. Plants and their parts were collected in their fresh and dry form and packed in polythene bags as well as pressed in old news papers and brought to laboratory for identification and further study.

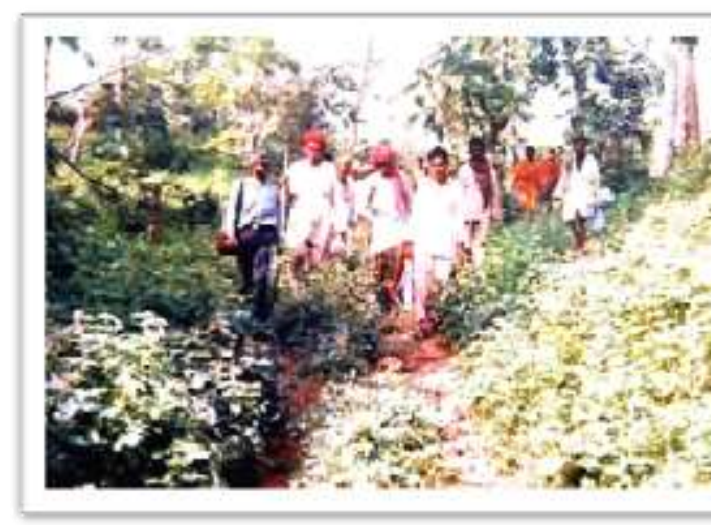

Fig. 1 Survey of study area

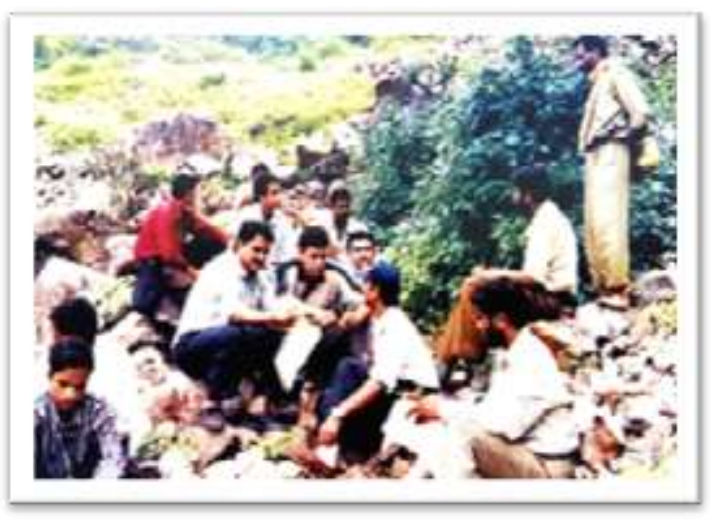

Fig. 2 Data collection with interview and group discussion

\section{OBSERVATIONS:}

It was observed that in every village of the study area, there are individuals who are regarded as especially knowledgeable or skilled in the treatment of animal diseases. Usually they keep animals themselves and most of them belong to pastoral communities. Some time their reputation extends only to their own village and they will be consulted only occasionally. Others draw clients from great distance and operate very much like a veterinary practitioners. Their degrees of specialization vary. A few are generalized and treat human as well as animals. Some of them are specialized in certain type of applications such as fractures or birthing problems and types of treatment (e.g. firing or message), or certain species, usually buffaloes and cows.

The treatment inventory of healer typically includes about 8-10 types of diseases. The most frequently are such as diarrhea, after birth retention, prolapsed of uterus, constipation, bloat, rheumatism, indigestion, blood in urine, fever etc. The THPs prepare medicines on the spot from plants that grows in their nearby environment of the village and other standard ingredients that are locally available such as ghee, oil and butter milk. 


\section{G.S. Deora ${ }^{1}$,International Journal of Ayurvedic\& Herbal Medicine 7(4) July.-Aug. 2017 (2746-2751)}

It was reported that single plant or combination of plant parts as a formulation is given to the animal by THPs. For the oral does special utensils are used made of plant parts. Further it was also observed that fresh and dry plant parts are given as fodder or mixed with cattle feed to treat some diseases.

The information was collected from the tribals during survey and it was observed that the main occupation of the tribal is agriculture and animal husbandry.

Efforts were made to collect local name of various animal diseases and plants used by THPs. In this chapter plants are arranged in following order:

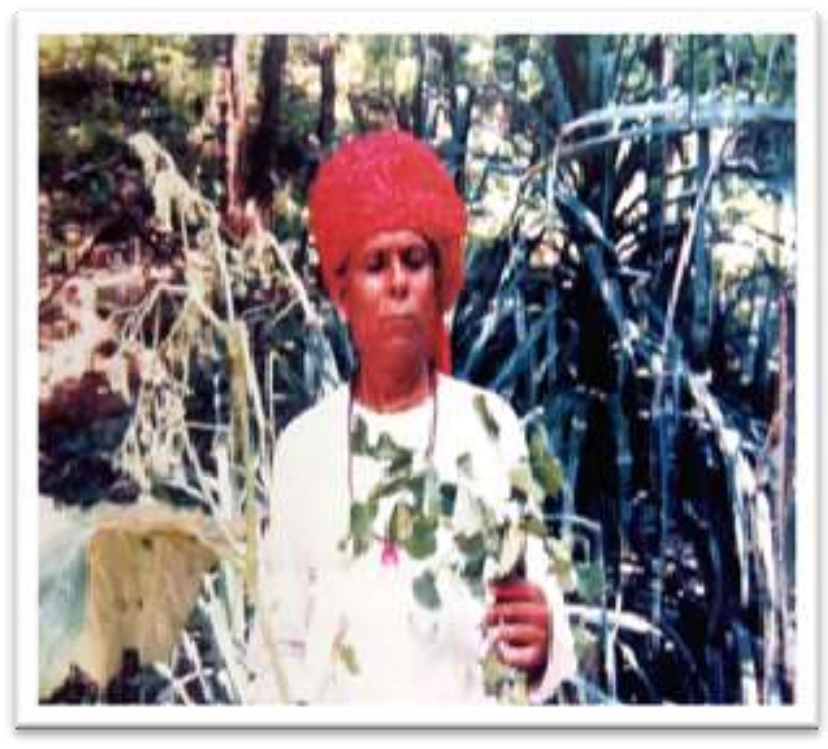

Fig.3 Identification of plant by ethno veterinarian

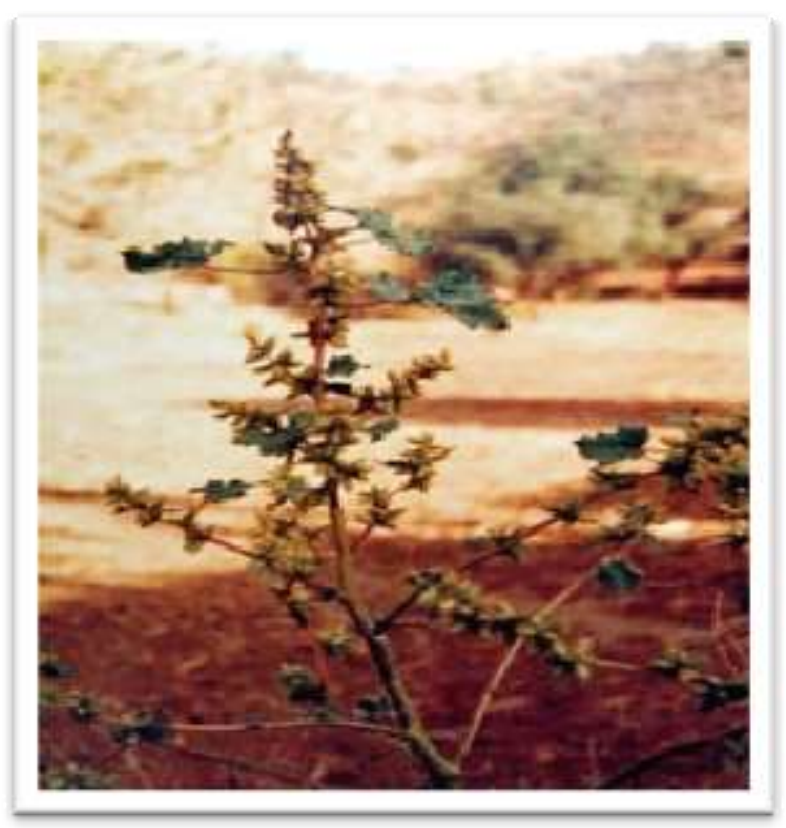

Fig. 5 Xanthium strumarium

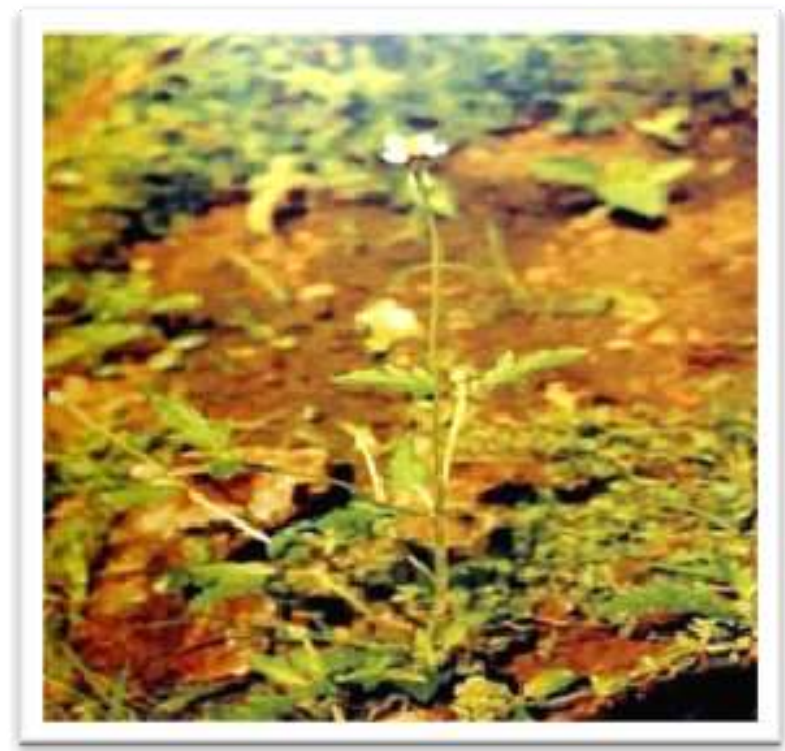

Fig.4 Tridaxprocumbens

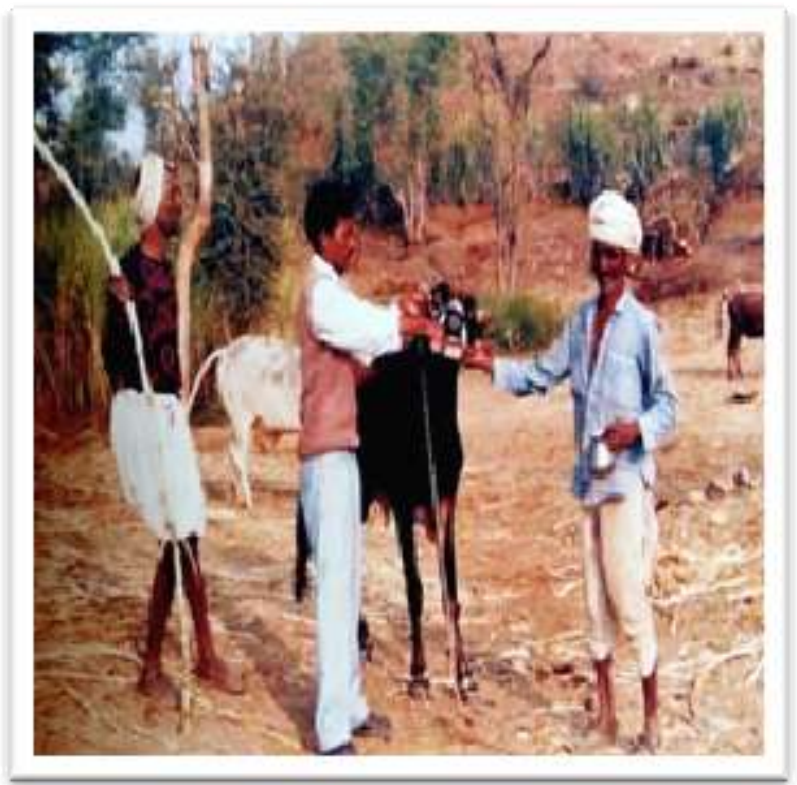

Fig. 6 THP -using plant made utensil for oral medicine dose 
G.S. Deora ${ }^{1}$,International Journal of Ayurvedic\& Herbal Medicine 7(4) July.-Aug. 2017 (2746-2751)

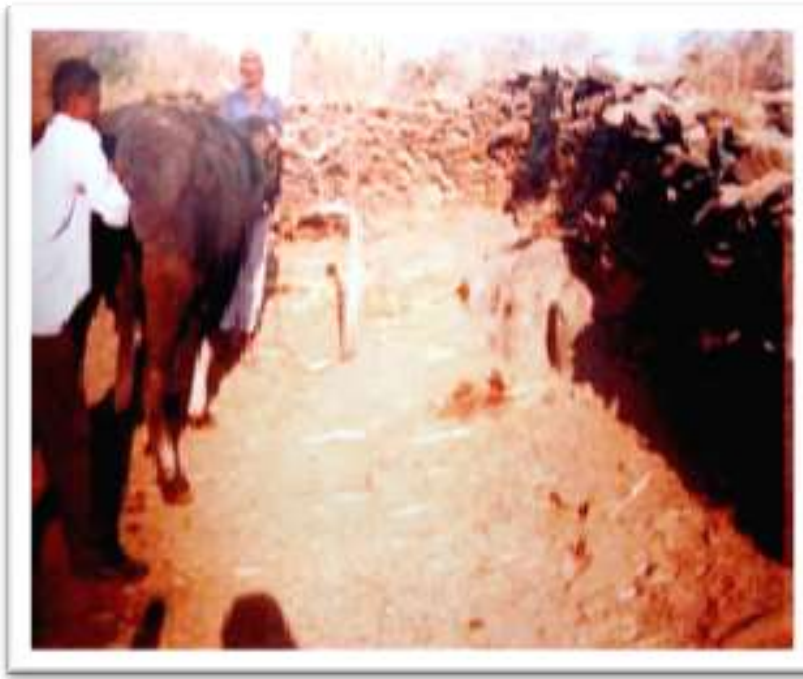

Fig. 7 THP-handling Uterus prolaps problem in Buffalo

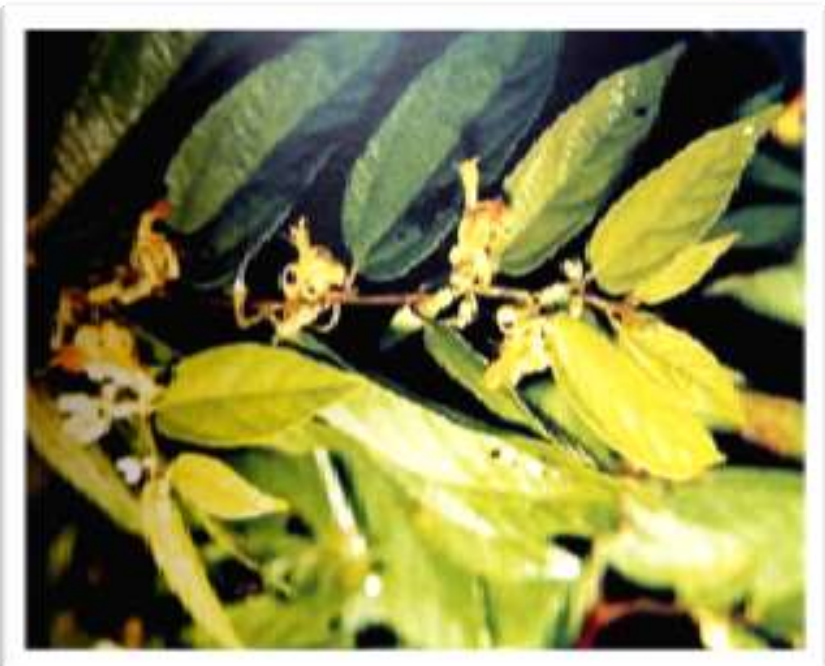

Fig. 8 Grewiatiliaefolia- Bone fracture (Root)

Botanical name, family, vernacular name, locality, habit and disease formulations suggested by THPs. are as follows-:

1. Ailanthus excelsaRoxb.

Ln.-Adua

Habit - Tree

\section{Simaroubiaceae}

Loc.-PanarvaSom,Kotra, Banswara, Dungarpur, Udaipur

Leaves paste is applied on body to- Control tick and lice. Bark + goat milk paste is applied to treatNose rope wound.

2. AmpelocissusamottianaPlanch

Habit - annual woody climber.

3. Anisomelesindica (Linn.) Ktze.

Ln. - Phulmajri

Habit - Annual herb.

Whole plant infusion is given in - Indigation.

Root paste infusion is given to treat- Bone- fracture, uterus dislocation and weakness of animal after delivery.

4. Aristolochiabracteata Retz.

Ln. - Kidamary

Habit - A creeping climber

Leaves juice is used to treat - Wound, Maggots in wound. Little quantity this juice is given to treat Tympanitis

5. Cassia occidentalis Linn.

Ln. - Malvipunwad

Habit - Annual herb.
Vitaceae

Loc - Kotra, Udaipur,

Labiatae

Loc- Kotra, Banswara, Chittorgarh, Dungarpur, Udaipur

\section{Aristolochiaceae}

Loc- Dungarpur, Udaipur

\section{Leguminosae}

Loc. - Chittorgarh, Dungarpur, Kotra, Rajasaman

Leaves paste is applied to treat - Eczema and other skin diseases. Seeds powder is mixed with cattle feed given to increases milk production.

6. ClerodendrumphlomidisLinn.

Ln. - Arnl
Verbenaceae

Loc. - Kotra, Udaipur 
Habit - Shrub.

Leaves juice is applied - Hooves rot, Maggots in wound.

7. DelonixalataGamble

Caesalpiniaceae

Ln. - Handeda

Loc- Banswara, Kotra,

Habit - Tree

Udaipur

Crushed stem bark decoction is given to treat - Dysentery, diarrhea.

8. Dichrostachyscinera $W \& A$

Ln. - Amna

Habit - Tree

Stem bark grinded is used - Urinary complaints.

9. EnicostemmahyssopifolumBlume.

Ln. - Naami

Habit - An annual herb.

\section{Leguminosae}

Loc. - Banswara, Dungarpur, Udaipur

\section{Gentianaceae}

Loc. -Banswara, Rajsamand, Udaipur

\section{Euphorbiaceae}

Loc.-Banswara, Udaipur

Ln.-Chhotidudhi

Habit - Annual herb.

Whole plant is crushed and given to eat with Chapati to treat Excessive bleeding after delivery.

11. Gloriosasuperba Linn.

\section{Liliaceae}

Ln. - Kalihari

Loc. - Udaipur, Rajsamand

Habit - an annual climber.

Root paste or juice is applied against - Maggots is wound, external abscess.

12. GrawiatiliaefoliaVahl.

Ln. - Farangdee

Habit - Shrub.

Root infusion is given to treat - Bone fracture.

13. Jatropacurcas Linn.

Ln. - Ratanjot

Habit - Small tree.
Tiliaceae

Loc. - Dungarpur, Pratapgarh, Udaipur

\section{Euphorbiaceae}

Loc - Banswara, Dungarpur, Rajasamand, Udaipur

Latex is used as antiseptic during uterus setting to treat Uterus dislocation. Latex is applied on wound to treat Bleeding from fresh wound.

14. Leptadeniapyrotechnica (Forsk) Decne

Asclepiadaceae

Ln. - Kheep

Loc. - Dungarpur, Pratapgarh,

Habit - Shurb.

Udaipur

Whole plant is crushed get infusion of whole plant is given Uterus porlaps, Stomach disorders.

15. Maeruaarenaria Hook F. Th.

Capparidaceae

Ln. - Jethivela

Loc. -Dungarpur, Kotra,

Habit - Woody climber. Udaipur,

Crushed root + Butter milk is given to - Tympanitis, Throt swelling.

16. Tridexprocumbens Linn.

Asteraceae

Ln. - Kalali

Loc. - Banswara, Chittorgarh,

Habit - Annual herb. Udaipur

Leaves juice is used to treat - Bleeding from fresh wound, Maggots is wound.

17. UrgineaindicaKunth.

Liliaceae 
G.S. Deora ${ }^{1}$,International Journal of Ayurvedic\& Herbal Medicine 7(4) July.-Aug. 2017 (2746-2751)

Ln. - Kolikando

Loc- Kotra, Pratapgarh, Udaipur

Habit - An annual herb.

Crushed bulb juice is applied used - Maggots in wound. Roasted bulb is Crushed and tie on affected part to treat External abscess.

18. Vilexnegundo Linn.

\section{Verbenaceae}

Ln. - Nirgundi

Habit - Shurb.Rajasmand, Udaipur

Loc. - Kotra, Pratapgarh,

Root juice is applied to treat - Mastitis. Leaves juice is used externally applied for - Wound healing.

19. Xanthium strumarium Linn.

Ln. - Andhayo

Habit - Annual herb.

Asteraceae

Loc. - Dungarpur, Kotra,

Udaipur

Leaves juice is used externally used for - Wound healing and Maggots is wound.

Note-: Ln.-Local name, Loc-Locality.

\section{ACKNOWLEDGEMENT}

Authors are thankful to all the tribals of the study area who provided oral information about the local name of plants and their uses for traditional animal health care and to cure different types of diseases. Authors are also thankful to UGC for providing financial assistance through CAS program in the Department of Botany Jai NarainVyas University Jodhpur (Rajasthan).

\section{REFERENCES:}

1. Alemu. L. 1993. Studies on the traditional medicinal plants of veterinary importance around Bihar Dar. DVM Thesis, faculty of Veterinary medicine, Addis Ababa University, Ethiopia.

2. Catley,A and A. A. Mohammed. 1996. Ethno-veterinary knowledge in Sanag region, Somali land (Part II): Notes on local methods of treating and preventing livestock diseases, Nomadic peoples 39: 135-146.

3. ShaheenHamed K. 1997.Traditional veterinary practices in Rural Medak, India.Proceeding of International Conference on Ethno- veterinary, 4-6 Nov. 1997. Pune P. 57-59

4. Kohler - Rollefson. I. and Rathore, H.S. 1997. Raikas of Rajasthan LEISA: ILFA Newsletter 13(2) : 36 .

5. McCrokle Constance and Evelyn Mathias-Mundy, 1992.Ethanoveterinary medicinal in Africa. Africa 62(1) : 59-93.

6. McCrokle Constance. 1994. Ethanoveterinary medicine R\&D and genger in the ITDG/ Kenya RAPP. Unpublished Consultancy Report.IT Kenya, Nairobi, Kenya.

7. Pal, D.C. 1980 Observation on folklore about plants used in veterinary medicine in Bengal, Bihar and Orissa state. Bull. Botanical Survey of India 22:26-99.

8. Pande, C.B. and Vijay Kumar. 1994. A Study of immunomodulating action of Zeetress. Proceeding of scientific symposium on recent Advances in veterinary microbiology B.C.K.V.V. Nadia, W.B. India pp 53-55.

9. Rangnekar, S.D. and D.V. Rangnekar, 1992.Involment of women and children in goat keeping in some villages of Gujrat and Rajasthan. Proceeding of Vth International Conference on goats, held at New Delhi pp. 420-426.

10. Sebastian, M.K. 1984. Plantas used as veterinary medicine galactogoues and fodder in the forest areas of Rajasthan. Texon. Botany 5:785-788. 